\title{
Effect of Leaf Rust on Grain Yield and Yield Traits of Durum Wheats with Race-Specific and Slow-Rusting Resistance to Leaf Rust
}

\author{
S. A. Herrera-Foessel, Department of Forest Mycology and Pathology, Swedish University of Agricultural Sciences \\ (SLU), Box 7026, S 75007 Uppsala, Sweden; R. P. Singh, International Maize and Wheat Improvement Center \\ (CIMMYT), Apdo. Postal 6-641, 06600 México, D.F., México; J. Huerta-Espino, Campo Experimental Valle de \\ México INIFAP, Apdo. Postal 10, 56230, Chapingo, Edo de México, México; J. Crossa, CIMMYT, México; and \\ J. Yuen and A. Djurle, Department of Forest Mycology and Pathology, SLU, Sweden
}

\begin{abstract}
Herrera-Foessel, S. A., Singh, R. P., Huerta-Espino, J., Crossa, J., Yuen, J., and Djurle, A. 2006. Effect of leaf rust on grain yield and yield traits of durum wheats with race-specific and slowrusting resistance to leaf rust. Plant Dis. 90:1065-1072.

Leaf rust, caused by Puccinia triticina, is an important disease of durum wheat (Triticum turgidum) in many countries. We compared the effectiveness of different types of resistance in International Maize and Wheat Improvement Center-derived durum wheat germ plasm for protecting grain yield and yield traits. In all, 10 durum wheat lines with race-specific resistance, 18 with slow-rusting resistance, and 2 susceptible were included in two yield loss trials sown on different planting dates in Mexico with and without fungicide protection under high disease pressure. Eight genotypes with race-specific resistance were immune to leaf rust. Durum wheat lines with slow-rusting resistance displayed a range of severity responses indicating phenotypic diversity. Mean yield losses for susceptible, race-specific, and slow-rusting genotypes were 51, 5 , and $26 \%$, respectively, in the normal sowing date trial and 71,11 , and $44 \%$ when sown late. Yield losses were associated mainly with a reduction in biomass, harvest index, and kernels per square meter. Slow-rusting durum wheat lines with low disease levels and low yield losses, as well as genotypes with low yield losses despite moderate disease levels, were identified. Such genotypes can be used for breeding durum wheat genotypes with higher levels of resistance and negligible yield losses by using strategies that previously have been shown to be successful in bread wheat.
\end{abstract}

Additional keyword: tolerance

Durum wheat (Triticum turgidum L.), an important crop in northwestern Mexico, previously was considered to be more resistant to leaf rust (caused by Puccinia triticina) than bread wheat (T. aestivum em thell.) (25). Significant yield losses due to leaf rust in durum wheat had not been recorded historically within the region and the resistance of the most popular durum cultivar, Altar C84, had remained effective for the 16 years following its release in 1984 (27). In 2001, a new P. triticina race, designated $\mathrm{BBG} / \mathrm{BN}$, was detected in northwestern Mexico, which had high virulence to Altar C84 and many other cultivars released in Mexico and other countries (27). Leaf rust epidemics during 2001, 2002, and 2003 in durum wheat caused estimated losses of US $\$ 32$ million (27). A new cultivar, Atil C2000, released just a year prior to the appearance of race $\mathrm{BBG} / \mathrm{BN}$, was expected to give a major

Corresponding author: S. A. Herrera-Foessel

E-mail: sybil.herrera@mykopat.slu.se

Accepted for publication 3 April 2006.

DOI: 10.1094/PD-90-1065

(C) 2006 The American Phytopathological Society boost to durum production in the region because of its at least $10 \%$ higher yield potential than the popular Altar C84 (27). However, Atil C2000 also was susceptible to race $\mathrm{BBG} / \mathrm{BN}$ and seed multiplication plans were suspended. More troubling, over $80 \%$ of the International Maize and Wheat Improvement Center (CIMMYT) durum wheat germ plasm collection showed high susceptibility to the new race. This forced durum wheat breeders and pathologists to shift their research and breeding emphasis to searching for resistant germ plasm and transferring resistance to high-yielding durum wheat lines. Durum wheat genotypes carrying racespecific resistance genes and those with varying levels of slow-rusting resistance were identified after screening thousands of breeding lines and collections from the durum wheat breeding program (27). A resistant cultivar, Jupare C2001, that showed immunity to race $\mathrm{BBG} / \mathrm{BN}$ was released in Mexico the same year, 2001. The genetic basis of effective race-specific resistance was determined in nine durum wheat lines, and five different resistance genes were identified (10). Resistance found in Jupare C2001 and two other genotypes involved two complementary genes, whereas the resistance of other genotypes was based on four different dominant or partially dominant genes.

Information on the effect of different types of resistance in protecting grain yield losses in durum is scarce. Singh et al. (27) evaluated losses for selected race-specific, slow-rusting, and susceptible durum genotypes under artificial inoculations. These were carried out late in the season due to quarantine restrictions that precluded inoculating field nurseries before natural infections were reported in farmers' fields. Despite late rust initiation, varying degrees of losses were reported for susceptible, race-specific, and slow-rusting durum genotypes.

The objectives of our study were to determine and compare the effectiveness of race-specific and slow-rusting resistance in reducing losses in grain yield and related yield traits when exposed to high leaf rust pressure.

\section{MATERIALS AND METHODS}

The 30 durum wheat genotypes included in our study (Table 1) were derived from CIMMYT germ plasm. Commercial Mexican cvs. Altar C84 and Atil C2000 were chosen as checks for their high susceptibility to race $\mathrm{BBG} / \mathrm{BN}$. The other 28 durum wheat lines were categorized as either race-specific resistant or slow rusting based on their reaction to leaf rust. A racespecific resistant genotype was identified by its incompatible reaction to $P$. triticina race $\mathrm{BBG} / \mathrm{BN}$, displaying immune to moderately resistant host response to infection (18). In contrast, a slow-rusting genotype was recognized by a reduced disease progress compared with a susceptible check despite its compatible (or susceptible) reaction (3). Jupare C2001, Somateria, Camayo, Storlom, Hualita, Guayacan 2, Pohowera, Llareta INIA, and Guayacan INIA carry either one dominant or two complementary race-specific leaf rust resistance genes (10). Llareta INIA and Guayacan INIA are Chilean cultivars and remain resistant in South America. Guayacan 2 and Guayacan INIA are sister selections from the same cross. The host response to infection of Quetru is moderately resistant to resistant, with uredinia surrounded by necrosis or strong chlorosis indicating race-specific resistance (18). The remaining 18 genotypes were classi- 
fied as slow rusting due to their susceptible host response in seedling and field tests but slower disease progress in the field compared with the susceptible checks Altar C84 and Atil C2000. The slow-rusting durum wheat lines Planeta 1 and Planeta 2 are sister selections from the same cross. Yavaros C79 is a Mexican cultivar released in 1979 but still grown in several North African countries as well as in Spain.

Two yield loss trials, sown on normal (22 November 2003) and late (10 December 2003) planting dates, were established at CIMMYT's research station near Ciudad Obregón, Sonora, in northwestern Mexico, during the 2003-04 crop season. The reason for establishing two planting dates was to expose the crop to high disease pressure at different growth stages. Plants sown on the late planting date were expected to receive higher disease pressure in earlier developmental stages compared with the plants sown on the normal planting date. Planting arrangements for each trial followed a paired-split-plot arrangement with fungicide protected and nonprotected (rusted) treatments as main plots and durum wheat genotypes as subplots. Nine incomplete blocks and three replicates were used for each trial. Each subplot consisted of three rows, $3 \mathrm{~m}$ long and planted $13 \mathrm{~cm}$ apart, on top of two raised beds of $0.8 \mathrm{~m}$ width. The immune cv. Jupare C2001 was planted as a resistant border around the experiment to protect the experiment from incoming inoculum from the neighboring fields. Hill plots of the susceptible cv. Atil C2000 were planted in the middle of a 1-m pathway on both sides of the experimental plots. The trials were maintained under optimal growing conditions using recommended management practices. Three supplementary furrow irrigations were given at regular intervals.
Herbicides and mechanical cultivations were used for weed control.

The leaf rust epidemic was initiated by spraying the spreader hill plots twice, on 20 and 21 January 2004, with urediniospores of $P$. triticina race $\mathrm{BBG} / \mathrm{BN}$ suspended in the lightweight mineral oil Soltrol 170. The avirulence and virulence formula of the race is as follows (27): Lr1,2a, 2b,2c,3,3bg, 3ka, 9, 12,13,14a, 15,16, $17,18,19,21,24,25,26,27+31,28,29,30,32,34$, $35,36,37 / 10,11,14 b, 20,23,33$.

To keep protected plots free from leaf rust, the fungicide tebuconazole (Folicur $125 \mathrm{~g}$ a.i./ha) was applied on 10 and 26 February and 8 March 2004. Leaf rust severity and reaction were evaluated for each plot at weekly intervals using the modified Cobb Scale (15) and the host response scale described in Roelfs et al. (18), respectively. The first rust data were recorded when most plants were at growth

Table 1. Relative area under the disease progress curve (rAUDPC) and final disease ratings for 30 durum wheat genotypes planted on two dates in Mexico and their cross and selection identification (CID and SID, respectively) ${ }^{\mathrm{a}}$

\begin{tabular}{|c|c|c|c|c|c|c|c|c|}
\hline \multirow[b]{2}{*}{ Group, genotype $^{d}$} & \multirow[b]{2}{*}{ CID } & \multirow[b]{2}{*}{ SID } & \multicolumn{3}{|c|}{$\operatorname{rAUDPC}(\%)^{\mathbf{b}}$} & \multicolumn{3}{|c|}{ Final disease rating $(\%)^{\mathrm{c}}$} \\
\hline & & & Normal & Late & Difference $^{\mathrm{e}}$ & Normal & Late & Difference $^{\mathrm{e}}$ \\
\hline \multicolumn{9}{|l|}{ Susceptible } \\
\hline Atil C2000 & 148682 & 27 & 88 & 100 & $12 * *$ & 87 & 100 & $13^{* *}$ \\
\hline Altar C84 & 50955 & 8 & 100 & 99 & -1 & 100 & 100 & 0 \\
\hline Mean & $\ldots$ & $\ldots$ & 94 & 100 & $6^{\mathrm{f}}$ & 93 & 100 & $7 \mathrm{~g}$ \\
\hline \multicolumn{9}{|l|}{ Race-specific } \\
\hline Jupare C2001 & 154368 & 14 & 0 & 0 & 0 & 0 & 0 & 0 \\
\hline Somateria & 126471 & 38 & 0 & 0 & 0 & 0 & 0 & 0 \\
\hline Camayo & 150161 & 24 & 8 & 10 & 2 & 13 & 18 & 5 \\
\hline Storlom & 154625 & 34 & 0 & 0 & 0 & 0 & 0 & 0 \\
\hline Hualita & 148658 & 47 & 0 & 0 & 0 & 0 & 0 & 0 \\
\hline Guayacán 2 & 145219 & 5 & 0 & 0 & 0 & 0 & 0 & 0 \\
\hline Pohowera & 88960 & 4 & 0 & 0 & 0 & 0 & 0 & 0 \\
\hline Llareta INIA & 375518 & 0 & 0 & 0 & 0 & 0 & 0 & 0 \\
\hline Guayacán INIA & 375517 & 0 & 0 & 0 & 0 & 0 & 0 & 0 \\
\hline Quetru & 133180 & 32 & 13 & 34 & $20 * *$ & 8 & 57 & $48 * *$ \\
\hline Mean & $\ldots$ & $\ldots$ & 2 & 4 & $2^{\mathrm{f}}$ & 2 & 8 & $5^{\mathrm{g}}$ \\
\hline \multicolumn{9}{|l|}{ Slow-rusting } \\
\hline Snitan & 142841 & 18 & 35 & 49 & $15^{* *}$ & 43 & 57 & $13 * *$ \\
\hline Guanay & 142206 & 34 & 23 & 44 & $21 * *$ & 30 & 53 & $23 * *$ \\
\hline Huasito & 136741 & 33 & 19 & 34 & $15^{* *}$ & 27 & 50 & $23 * *$ \\
\hline Playero & 295416 & 64 & 17 & 22 & 4 & 20 & 23 & 3 \\
\hline Molinero & 295535 & 43 & 27 & 25 & -2 & 37 & 33 & -3 \\
\hline Planeta 1 & 295822 & 14 & 9 & 5 & -4 & 10 & 5 & -5 \\
\hline Planeta 2 & 295822 & 15 & 12 & 10 & -2 & 13 & 15 & 2 \\
\hline Piquero & 261972 & 44 & 13 & 17 & 4 & 17 & 18 & 2 \\
\hline Bergand & 259827 & 27 & 18 & 12 & -6 & 22 & 17 & -5 \\
\hline Lile & 203023 & 59 & 38 & 42 & 4 & 50 & 73 & $23 * *$ \\
\hline Amic & 283419 & 39 & 20 & 25 & 5 & 27 & 33 & 7 \\
\hline Manutara & 283823 & 27 & 48 & 56 & $8 *$ & 60 & 80 & $20 * *$ \\
\hline Knipa & 328070 & 20 & 10 & 9 & -1 & 12 & 13 & 2 \\
\hline Tadiz & 328565 & 26 & 29 & 47 & $18 * *$ & 33 & 57 & $23 * *$ \\
\hline Trile & 327375 & 15 & 12 & 10 & -2 & 15 & 12 & -3 \\
\hline Tagua & 327700 & 31 & 27 & 19 & $-8 *$ & 33 & 20 & $-13^{* *}$ \\
\hline Cuca & 261416 & 147 & 48 & 47 & -1 & 57 & 63 & 7 \\
\hline Yavaros C79 & 56343 & 13 & 37 & 25 & $-12 * *$ & 43 & 33 & $-10 *$ \\
\hline Mean & $\ldots$ & $\ldots$ & 25 & 28 & $3^{\mathrm{f}}$ & 31 & 36 & $5^{\mathrm{g}}$ \\
\hline
\end{tabular}

${ }^{\text {a }}$ Normal $=$ normal-sown trial, Late $=$ late-sown trial, and $*$ and $* *=$ significant at $P=0.05$ and 0.01 , respectively.

${ }^{\mathrm{b}}$ rAUDPC of the genotypes was relative to the most susceptible check within each planting date. Least significant difference (LSD) from combined analysis $=7(P=0.05)$ and $9(P=0.01)$.

${ }^{\mathrm{c}}$ Final disease rating is the last rating and follows the modified Cobb scale (15). LSD from combined analysis $=10(P=0.05)$ and $13(P=0.01)$.

${ }^{\mathrm{d}}$ Resistance group and genotype.

${ }^{\mathrm{e}}$ Difference $=$ disease value of late planting date - disease value of normal planting date.

${ }^{\mathrm{f}}$ LSD values $10(P=0.05)$ and $15(P=0.01)$ were used for comparing mean rAUDPC of the three resistance groups: susceptible, race-specific resistant, and slow rusting.

${ }^{\mathrm{g}}$ LSD values $14(P=0.05)$ and $22(P=0.01)$ were used for comparing mean final disease ratings of the three resistance groups: susceptible, race-specific resistant, and slow rusting. 
stage DC 69 (anthesis complete) in the normal-sown trial and DC 52 (one-quarter of inflorescence emerged) in the late-sown trial (34). Leaf rust responses were recorded until the most susceptible line showed $100 \%$ leaf rust severity (i.e. when most durum wheat lines, including the susceptible, were at DC77 [late milk] at the normal sowing date and at DC83 [early dough] in the late-sown trial). Using the weekly ratings, the area under the disease progress curve (AUDPC) was calculated using an Excel program available at CIMMYT following the formula given in Roelfs et al. (18). The relative AUDPC (rAUDPC) was calculated by dividing the mean AUDPC of entries with the highest AUDPC value displayed by the susceptible checks.

For determining yield traits, 50 productive culms from each plot were cut randomly at ground level prior to harvesting, placed in paper bags, and weighed after drying in an oven for 2 days at $75^{\circ} \mathrm{C}$. The 50 culms then were threshed carefully and kernels dried once again for 2 days at the same temperature and then weighed. Grain yield was obtained by harvesting the entire plot $\left(4.8 \mathrm{~m}^{2}\right)$. To standardize grain yield at $12 \%$ moisture, a sample of about $100 \mathrm{~g}$ of harvested grains was weighed before and after oven drying for 2 days. Counting and weighing 400 unbroken grains per plot determined the kernel weight. Data from the 50 culms, grain yield, and the kernel weight were used in calculating harvest index (kernel weight/culm weight), biomass (grain yield/harvest index), kernels per square meter, spikes per square meter, number of kernels per spike, and kernel weight according to Sayre et al. (22). In addition, the test weight (hectoliter weight) was determined by using a test weight machine. Days from germination to heading and from germination to physiological maturity also were recorded for each plot during the crop season.

An individual split-plot analysis for each of the two trials differing in planting date and a combined split-plot analysis across trials were performed for grain yield and yield traits using the software package ASREML (8). Before analyzing grain yield, a spatial analysis (2) was conducted to account for soil heterogeneity and other sources of variability for each trial and across trials. Genotypes were considered as random whereas treatments as fixed. The AUDPC and final disease rating (FDR) were analyzed individually and combined across trials as complete block or incomplete block depending on whether the block effect was significant. The genotypic correlations (24) between the grain yield and yield traits were computed using the Statistical Analysis System (21). Only mean values over the trials for the yield traits are presented.

\section{RESULTS}

Leaf rust development and expression of resistance. Leaf rust pressure was high and uniform throughout the experiment. The fungicide-protected plots remained free from leaf rust during the entire crop season. The 2 susceptible cultivars and the 18 slow-rusting genotypes displayed compatible host responses to infection. Most genotypes with race-specific resistance were either immune or near immune (i.e., showed hypersensitive flecking). Only Camayo and Quetru displayed resistant to moderately resistant host responses to infection, manifested as small uredinia surrounded by chlorosis.

The mean rAUDPC and FDR of susceptible, race-specific resistant, and slowrusting genotypes differed significantly from each other in both trials and in combined analysis across trials (Table 1). The two susceptible checks, Altar C84 and Atil C2000, had the highest rAUDPC values and FDR in both trials. In the normal-sown trial, the mean rAUDPC and FDR for susceptible, race-specific resistant, and slowrusting genotypes were 94 and 93, 2 and 2, and 25 and $31 \%$, respectively. In the latesown trial, the mean rAUDPC and FDR were 100 and 100, 4 and 8, and 28 and $36 \%$ for the susceptible, race-specific resistant, and slow-rusting genotypes, respectively.

In individual analyses, all genotypes with race-specific resistance, except Camayo and Quetru, were immune and had an rAUDPC and FDR of $0 \%$. The rAUDPC and FDR of 10 and $16 \%$, respectively, for Camayo did not change significantly in the two trials, whereas a significant increase, from 13 to 34 and from 8 to $57 \%$, respectively, could be observed for Quetru in the late-sown trial. The slowrusting genotypes showed large variations in AUDPC and FDR values, indicating phenotypic diversity for slow-rusting resistance in durum wheat. Although genotypes such as Planeta 1, Planeta 2, Knipa, Piquero, and Trile displayed lower leaf rust responses (rAUDPC and FDR below $20 \%$ ), the disease progressed faster in other genotypes, such as Snitan, Manutara, and Cuca. About half of the slow-rusting genotypes had significantly higher AUDPC and FDR values in the late-sown trial compared with the normal-sown trial. In contrast, Tagua and Yavaros C79 had significantly lower disease values in the latesown trial.

In the normal-sown trial, slow-rusting Planeta 1, Knipa, Planeta 2, Trile, and Piquero displayed rAUDPC values either lower or similar to that of the race-specific Quetru (rAUDPC of 13\%). In the latesown trial, these genotypes, except Piquero, also had similar or lower values compared with the race-specific resistant Camayo (rAUDPC of 10\%). A majority of the slow-rusting genotypes had lower rAUDPC values compared with Quetru in the late-sown trial.

For the two susceptible checks, the rAUDPC and FDR were significantly lower for Atil C2000 (88 and 87\%, respectively) compared with Altar C84 (100 and $100 \%$, respectively) in the normal-sown trial, whereas the leaf rust responses in the late-sown trial were similar for the two checks.

Grain yield and yield losses. The mean grain yield was significantly higher for fungicide-protected plots (6.5 and $4.8 \mathrm{t} / \mathrm{ha}$ for normal- and late-sown trials, respectively) compared with the nonprotected plots (5.1 and 3.2 t/ha for normal- and latesown trials, respectively). On average, yields were lower in the late-sown trial (4.0 t/ha) compared with the normal-sown trial $(5.8 \mathrm{t} / \mathrm{ha})$. The difference in yield was expected because leaf rust infection was initiated at an earlier plant development stage in the late-sown trial compared with the normal-sown trial.

In the normal-sown trial, the average yield losses for susceptible, race-specific resistant, and slow-rusting genotypes were 51,5 , and $26 \%$, respectively (Table 2 ). The average yield loss for the genotypes with race-specific resistance was nonsignificant in the normal-sown trial. In the late-sown trial, the average yield losses were higher and significant for all groups: $71 \%$ for the susceptible genotypes, $11 \%$ for genotypes with race-specific resistance, and $44 \%$ for genotypes with slow-rusting resistance.

Of the two susceptible checks, the yield loss for Altar C84 (33\%) was almost half of that for Atil C2000 (61\%) in the normalsown trial, despite the fact that the rAUDPC and FDR of Altar C84 were significantly higher than those for Atil C2000. In the late-sown trial, the yield losses for Atil C2000 and Altar C84 were similar (74 and $67 \%$, respectively; Table 2).

In the individual analyses for each genotype, the yield losses were negligible for most of the genotypes with race-specific resistance. In the individual and combined analysis across trials, only Camayo and Quetru of the race-specific resistant durum genotypes had significant yield losses. This was not surprising because Camayo and Quetru were the only genotypes with low to intermediate leaf rust responses when the rest of the race-specific resistant genotypes displayed immune responses. In the individual analysis for each of the trials, the immune Guayacan 2 also had a significant yield loss and, in the late-sown trial, the immune genotypes Storlom, Llareta INIA, and Guayacan INIA had significant yield losses.

All slow-rusting genotypes had significant yield losses in both trials. In the normal-sown trial, the yield losses varied from 17 to $40 \%$ whereas, in the late-sown trial, higher losses of 25 to $62 \%$ were obtained. The slow-rusting Guanay, Planeta 2, Manutara, and Knipa had lower yield losses (below 20\%) in the normal-sown trial than the rest of the slow-rusting durum wheat lines. Planeta 1, Knipa, and Trile had lower yield losses (below 31\%) 
in the late-sown trial. In the normal-sown trial, none of the slow-rusting genotypes had lower losses than any of the racespecific resistant genotypes. In the latesown trial, there were several slow-rusting genotypes that had lower losses than the race-specific resistant Quetru.

Yield traits. The mean biomass and harvest index across trials of the genotypes with race-specific resistance were not reduced in the nonprotected treatment when compared with the protected treatment (Table 3). The mean biomass and harvest index for susceptible and slow-rusting genotypes were significantly reduced. In individual analyses, only Camayo and Quetru among the durum wheat lines with race-specific resistance showed a reduction in biomass in the nonprotected treatment. Meanwhile, the two susceptible and all slow-rusting durum wheat lines, except Guanay, Planeta 1, Planeta 2, and Trile, had a significant biomass reduction in the nonprotected treatment. In the individual analyses of harvest index, only Jupare C2001, Llareta INIA, and Quetru among the durum wheat lines with race-specific resistance had significant reductions in the nonprotected treatment. The two susceptible and all slow-rusting genotypes, except Knipa, had significant reduction in harvest index in the nonprotected treatment.

Mean kernel weight, kernels per square meter, and test weight across trials were not reduced significantly for genotypes with race-specific resistance in the nonprotected plots compared with the protected plots (Table 4). These components were significantly lower in nonprotected treatments for the susceptible and genotypes with slow-rusting resistance.

In individual analyses for kernel weight, none of the durum wheat lines with racespecific resistance, with the exceptions of Camayo and Quetru, had a significant reduction in kernel weight in the nonprotected plots. The two susceptible and all durum wheat lines with slow-rusting resis- tance, except Knipa, had a significant reduction in kernel weight in the nonprotected plots. None of the durum wheat lines with race-specific resistance had a lower number of kernels per square meter in nonprotected plots. However, all susceptible and a majority of the genotypes with slow-rusting resistance (11 of 18 genotypes) had significant reductions in number of kernels per square meter under rust pressure.

In individual analyses for test weight, among the durum wheat lines with racespecific resistance, only Quetru had a significant reduction in nonprotected plots. The two susceptible and all the genotypes with slow-rusting resistance, except for Bergand, Manutara, Knipa, and Trile, had significant reductions in test weight under rust pressure.

The number of kernels per spike was not significantly reduced for any genotype in the nonprotected treatment, although the difference in magnitude was sizable for the

Table 2. Grain yields (t/ha) and losses (\%) for 30 durum wheat genotypes and for the three resistance groups (susceptible, race-specific resistant, and slowrusting) under fungicide-protected (Prot) and nonprotected (Nonprot) treatments in normal- and late-sown trials and across trials ${ }^{\mathrm{a}}$

\begin{tabular}{|c|c|c|c|c|c|c|c|c|c|}
\hline \multirow[b]{2}{*}{ Group, genotype ${ }^{\mathrm{e}}$} & \multicolumn{3}{|c|}{ Normal-sown trial $^{b}$} & \multicolumn{3}{|c|}{ Late-sown trial $^{c}$} & \multicolumn{3}{|c|}{ Across trials $^{d}$} \\
\hline & Prot & Nonprot & Loss $(\%)$ & Prot & Nonprot & Loss $(\%)$ & Prot & Nonprot & Loss $(\%)$ \\
\hline \multicolumn{10}{|l|}{ Susceptible } \\
\hline Atil C2000 & 8.04 & 3.14 & $60.9 * *$ & 5.22 & 1.37 & $73.8 * *$ & 6.53 & 2.38 & $63.5^{* *}$ \\
\hline Altar C84 & 6.58 & 4.39 & $33.4 * *$ & 4.57 & 1.50 & $67.1 * *$ & 5.61 & 2.94 & $47.7 * *$ \\
\hline Mean & 7.41 & 3.62 & $51.1 * * \mathrm{f}$ & 4.88 & 1.44 & $70.5^{* * \mathrm{~g}}$ & 6.15 & 2.46 & $60.0 * * \mathrm{~h}$ \\
\hline \multicolumn{10}{|l|}{ Race-specific } \\
\hline Jupare C2001 & 7.06 & 6.86 & 2.7 & 5.54 & 5.26 & 5.1 & 6.25 & 5.99 & 4.1 \\
\hline Somateria & 4.80 & 4.57 & 4.9 & 4.10 & 4.31 & -5.0 & 4.51 & 4.51 & -0.2 \\
\hline Camayo & 6.91 & 5.92 & $14.3 * *$ & 5.04 & 4.02 & $20.2 * *$ & 5.94 & 4.95 & $16.7 * *$ \\
\hline Storlom & 6.55 & 6.26 & 4.4 & 4.70 & 4.04 & $14.1^{*}$ & 5.63 & 5.12 & 8.9 \\
\hline Hualita & 6.65 & 6.18 & 7.0 & 4.75 & 4.64 & 2.2 & 5.67 & 5.42 & 4.4 \\
\hline Guayacan2 & 6.99 & 6.01 & $14.0 *$ & 5.62 & 5.06 & $9.9 *$ & 6.24 & 5.53 & 11.3 \\
\hline Pohowera & 4.74 & 4.11 & 13.4 & 3.07 & 2.90 & 5.4 & 3.97 & 3.63 & 8.4 \\
\hline Llareta INIA & 6.58 & 6.22 & 5.6 & 4.77 & 4.21 & $11.7^{*}$ & 5.64 & 5.17 & 8.3 \\
\hline Guayacan INIA & 6.01 & 6.45 & -7.3 & 5.43 & 4.57 & $15.9 * *$ & 5.78 & 5.43 & 5.9 \\
\hline Quetru & 6.89 & 5.81 & $15.8 *$ & 5.50 & 3.22 & $41.5^{* *}$ & 6.19 & 4.43 & $28.4 *$ \\
\hline Mean & 6.29 & 5.98 & $4.8^{\mathrm{f}}$ & 4.87 & 4.33 & $11.2^{* \mathrm{~g}}$ & 5.58 & 5.16 & $7.6^{\mathrm{h}}$ \\
\hline \multicolumn{10}{|l|}{ Slow-rusting } \\
\hline Snitan & 7.25 & 5.41 & $25.4 * *$ & 5.77 & 3.00 & $48.0^{* *}$ & 6.49 & 4.17 & $35.7 * *$ \\
\hline Guanay & 5.90 & 4.88 & $17.3 * *$ & 5.17 & 2.49 & $51.9 * *$ & 5.63 & 3.64 & $35.4 * *$ \\
\hline Huasito & 6.27 & 4.73 & $24.7 * *$ & 4.94 & 2.72 & $44.9 * *$ & 5.63 & 3.73 & $33.8 * *$ \\
\hline Playero & 5.95 & 4.24 & $28.8 * *$ & 3.66 & 1.77 & $51.6 * *$ & 4.84 & 3.05 & $36.9 * *$ \\
\hline Molinero & 6.50 & 4.92 & $24.2 * *$ & 5.05 & 2.82 & $44.3 * *$ & 5.80 & 3.87 & $33.3 * *$ \\
\hline Planeta 1 & 6.21 & 4.81 & $22.5^{* *} *$ & 4.46 & 3.13 & $29.8 * *$ & 5.34 & 3.99 & $25.3 * *$ \\
\hline Planeta 2 & 6.26 & 5.21 & $16.6^{* *}$ & 4.82 & 2.70 & $44.0 * *$ & 5.56 & 3.90 & $29.9 * *$ \\
\hline Piquero & 6.66 & 4.39 & $34.2 * *$ & 4.41 & 2.04 & $53.8 * *$ & 5.53 & 3.23 & $41.6 * *$ \\
\hline Bergand & 6.14 & 4.40 & $28.4 * *$ & 5.15 & 3.06 & $40.6^{* *}$ & 5.66 & 3.76 & $33.6 * *$ \\
\hline Lile & 6.83 & 5.18 & $24.1 * *$ & 4.40 & 2.57 & $41.6^{* *}$ & 5.59 & 3.87 & $30.7 * *$ \\
\hline Amic & 6.54 & 5.09 & $22.1 * *$ & 4.90 & 3.17 & $35.2 * *$ & 5.73 & 4.14 & $27.8 * *$ \\
\hline Manutara & 7.07 & 5.84 & $17.4 * *$ & 5.93 & 3.73 & $37.2 * *$ & 6.50 & 4.69 & $27.9 * *$ \\
\hline Knipa & 6.02 & 4.81 & $20.2 * *$ & 4.51 & 3.37 & $25.1 * *$ & 5.27 & 4.11 & $22.1 * *$ \\
\hline Tadiz & 6.07 & 3.65 & $39.9 * *$ & 3.99 & 1.54 & $61.5^{* *}$ & 5.06 & 2.65 & $47.6 * *$ \\
\hline Trile & 6.18 & 4.70 & $23.9 * *$ & 4.53 & 3.11 & $31.4 * *$ & 5.37 & 3.92 & $27.0 * *$ \\
\hline Tagua & 6.83 & 5.09 & $25.5 * *$ & 5.02 & 3.04 & $39.5^{* * *}$ & 5.91 & 4.07 & $31.2 * *$ \\
\hline Cuca & 7.35 & 5.24 & $28.7 * *$ & 5.77 & 2.54 & $56.0 * *$ & 6.56 & 3.82 & $41.7 * *$ \\
\hline Yavaros C79 & 6.39 & 4.53 & $29.1 * *$ & 4.85 & 2.94 & $39.4^{* *}$ & 5.62 & 3.78 & $32.8 * *$ \\
\hline Mean & 6.48 & 4.78 & $26.2 * * \mathrm{f}$ & 4.88 & 2.72 & $44.2 * * \mathrm{~g}$ & 5.68 & 3.75 & $34.0 * * \mathrm{~h}$ \\
\hline
\end{tabular}

${ }^{a}$ Loss $(\%)=($ protected yield - nonprotected yield $) \times 100 /$ protected yield; * and $* *=$ significant at $P=0.05$ and 0.01 , respectively.

${ }^{\mathrm{b}}$ Least significant difference $(\mathrm{LSD})=0.77(P=0.05)$ and $1.02(P=0.01)$.

${ }^{\mathrm{c}} \mathrm{LSD}=0.51(P=0.05)$ and $0.67(P=0.01)$.

${ }^{\mathrm{d}} \operatorname{LSD}=0.73(P=0.05)$ and $0.96(P=0.01)$.

e Resistance group and genotype.

${ }^{\mathrm{f}} \mathrm{LSD}=0.59(P=0.05)$ and $0.98(P=0.01)$ were used for comparing means of the three resistance groups for normal-sown trial

${ }^{\mathrm{g}} \mathrm{LSD}=0.53(P=0.05)$ and $0.88(P=0.01)$ were used for comparing means of the three resistance groups for late-sown trial.

${ }^{\mathrm{h}} \mathrm{LSD}=0.65(P=0.05)$ and $1.04(P=0.01)$ were used for comparing means of the three resistance groups across trials. 
susceptible durum wheat lines and for certain genotypes with slow-rusting resistance (data not presented). Similarly, a significant reduction in the number of spikes per square meter was observed only for susceptible checks and two genotypes that were slow rusting, Molinero and Tadiz (data not presented).

Average loss in number of kernels per square meter due to leaf rust were only $8.8 \%$ for the normal-sown trial compared with $28.9 \%$ for the late-sown trial (data not presented). This difference was expected because leaf rust appeared earlier in the late-sown trial and more seriously affected this trait, which typically is defined early in the plant's development. The average number of kernels per square meter in the normal-sown trial was 15,468 for fungicide-treated and 14,094 for rusted plots; and, in the late-sown trial, 13,232 in the fungicide-treated and 9,394 in the rusted plots.

Kernel weight was not expected to be affected differentially in the two trials because it is defined at the grain-filling stage (i.e., in a later developmental stage). The average losses in kernel weight of 13.3 and $10.3 \%$ for normal- and late-sown trials, respectively, were similar. However, the average kernel weight for the normalsown trial was $41.9 \mathrm{mg}$ in the fungicideprotected and $36.4 \mathrm{mg}$ in the nonprotected plots; and, in the late-sown trial, $37.1 \mathrm{mg}$ in the fungicide-protected and $33.2 \mathrm{mg}$ in the nonprotected plots. Hence, the average kernel weight was reduced irrespective of rust pressure in the late sown trial.

Genotypic correlations among disease, grain yield, and yield traits. In general, the genotypic correlations across trials among grain yield, yield losses, and yield-determining traits in the nonprotected treatment were higher compared with the correlations in the fungicideprotected treatment (Table 5). The rAUDPC and FDR were negatively correlated with grain yield and all yield traits, and highly positively correlated with yield losses. The negative correlation between disease components, rAUDPC, and FDR was particularly high with biomass and kernels per square meter. In the nonprotected treatments, grain yield was positively correlated with biomass, harvest index, kernel weight, kernels per square meter, kernels per spike, spikes per square meter, and test weight. In the protected treatment, yield was positively correlated with biomass, harvest index, kernel weight, kernels per square meter, and test weight. In addition, yield was negatively correlated to heading and physiological maturity in the protected treatment. Yield loss was negatively correlated with biomass, harvest index, kernel weight, kernels per square meter, kernels per spike, spikes per square meter, and test weight of the nonprotected treatments.

Yield losses also were negatively correlated to the number of days to physiological maturity in the nonprotected treatments, whereas no significant correlation was found between yield losses and the number of days to heading. Similarly, both

Table 3. Days to heading, biomass, and harvest index and their losses due to leaf rust for 30 durum wheat genotypes across trials in protected (Prot) and nonprotected (Nonprot) treatments ${ }^{\mathrm{a}}$

\begin{tabular}{|c|c|c|c|c|c|c|c|}
\hline \multirow[b]{2}{*}{ Group, genotype $^{d}$} & \multirow[b]{2}{*}{ Heading (days) ${ }^{\mathrm{e}}$} & \multicolumn{3}{|c|}{ Biomass $(\mathrm{t} / \mathrm{ha})^{\mathrm{b}}$} & \multicolumn{3}{|c|}{ Harvest index ${ }^{c}$} \\
\hline & & Prot & Nonprot & Loss $(\%)$ & Prot & Nonprot & Loss $(\%)$ \\
\hline \multicolumn{8}{|l|}{ Susceptible } \\
\hline Atil C2000 & 92 & 16.3 & 8.5 & $47.7 * *$ & 0.40 & 0.28 & $28.8 * *$ \\
\hline Altar C84 & 84 & 13.5 & 9.4 & $30.5 * *$ & 0.43 & 0.33 & $22.9 * *$ \\
\hline Mean & 88 & 14.9 & 9.0 & $39.6 * * \mathrm{f}$ & 0.42 & 0.30 & $28.6^{* * \mathrm{~g}}$ \\
\hline \multicolumn{8}{|l|}{ Race-specific } \\
\hline Jupare C2001 & 85 & 14.1 & 14.3 & -1.5 & 0.44 & 0.39 & $10.4 *$ \\
\hline Somateria & 97 & 13.7 & 12.7 & 6.9 & 0.33 & 0.34 & -2.6 \\
\hline Camayo & 87 & 14.2 & 12.0 & $14.9 *$ & 0.42 & 0.40 & 5.1 \\
\hline Storlom & 88 & 13.4 & 12.4 & 7.0 & 0.43 & 0.41 & 4.6 \\
\hline Hualita & 93 & 13.7 & 13.0 & 4.8 & 0.41 & 0.40 & 2.9 \\
\hline Guayacan2 & 85 & 14.2 & 13.2 & 6.8 & 0.43 & 0.40 & 7.7 \\
\hline Pohowera & 94 & 12.4 & 11.5 & 7.5 & 0.34 & 0.32 & 5.6 \\
\hline Llareta INIA & 87 & 13.5 & 13.5 & 0.1 & 0.41 & 0.36 & $12.1 *$ \\
\hline Guayacan INIA & 86 & 13.0 & 13.2 & -1.7 & 0.44 & 0.40 & 9.3 \\
\hline Quetru & 86 & 14.5 & 12.2 & $15.9^{*}$ & 0.41 & 0.36 & $12.4 *$ \\
\hline Mean & 89 & 13.7 & 13.3 & $2.7^{\mathrm{f}}$ & 0.40 & 0.38 & $4.9^{\mathrm{g}}$ \\
\hline \multicolumn{8}{|l|}{ Slow-rusting } \\
\hline Snitan & 86 & 14.7 & 11.7 & $20.0 * *$ & 0.43 & 0.35 & $18.8^{* *}$ \\
\hline Guanay & 89 & 13.8 & 11.9 & 13.8 & 0.40 & 0.31 & $23.0 * *$ \\
\hline Huasito & 91 & 14.6 & 12.0 & $18.0^{*}$ & 0.39 & 0.31 & $20.8^{* *}$ \\
\hline Playero & 93 & 13.2 & 10.4 & $20.8 * *$ & 0.38 & 0.30 & $21.1 * *$ \\
\hline Molinero & 84 & 14.9 & 11.5 & $23.1 * *$ & 0.39 & 0.33 & $14.8^{* *}$ \\
\hline Planeta 1 & 91 & 13.8 & 11.9 & 13.8 & 0.39 & 0.33 & $16.0 * *$ \\
\hline Planeta 2 & 91 & 13.9 & 12.0 & 13.2 & 0.40 & 0.33 & $18.4 * *$ \\
\hline Piquero & 94 & 14.5 & 11.3 & $22.5^{* *}$ & 0.38 & 0.29 & $22.7 * *$ \\
\hline Bergand & 90 & 13.9 & 11.5 & $17.0 *$ & 0.41 & 0.33 & $19.8 * *$ \\
\hline Lile & 86 & 13.7 & 11.0 & $19.3 * *$ & 0.42 & 0.35 & $16.4 * *$ \\
\hline Amic & 89 & 14.2 & 12.0 & $14.9 *$ & 0.40 & 0.34 & $15.7 * *$ \\
\hline Manutara & 85 & 14.9 & 12.3 & $17.5^{*}$ & 0.43 & 0.38 & $13.0^{* *}$ \\
\hline Knipa & 91 & 14.0 & 11.7 & $16.5^{*}$ & 0.38 & 0.34 & 9.7 \\
\hline Tadiz & 91 & 13.5 & 9.4 & $30.0 * *$ & 0.38 & 0.29 & $24.5^{* *}$ \\
\hline Trile & 94 & 13.6 & 11.8 & 13.4 & 0.40 & 0.33 & $16.8^{* *}$ \\
\hline Tagua & 89 & 14.5 & 11.5 & $20.4 * *$ & 0.40 & 0.35 & $13.4 *$ \\
\hline Cuca & 86 & 15.7 & 13.0 & $16.9^{* *}$ & 0.39 & 0.29 & $27.4 * *$ \\
\hline Yavaros C79 & 86 & 13.0 & 10.6 & $18.7 *$ & 0.44 & 0.36 & $19.0 * *$ \\
\hline Mean & 89 & 14.1 & 11.4 & $19.3^{* \mathrm{f}}$ & 0.40 & 0.33 & $19.2^{* * \mathrm{~g}}$ \\
\hline
\end{tabular}

a Asterisks * and $* *=$ significant at $P=0.05$ and 0.01 , respectively.

${ }^{\mathrm{b}}$ Least significant difference $(\mathrm{LSD})=2.0(P=0.05)$ and $2.6(P=0.01)$.

${ }^{\mathrm{c}} \mathrm{LSD}=0.04(P=0.05)$ and $0.06(P=0.01)$.

${ }^{\mathrm{d}}$ Resistance group and genotype.

${ }^{\mathrm{e}} \mathrm{LSD}=2(P=0.05)$ and $3(P=0.01)$.

${ }^{\mathrm{f}} \operatorname{LSD} 1.8(P=0.05)$ and $2.9(P=0.01)$ used for comparing mean biomass of the three resistance groups.

${ }^{\mathrm{g}} \operatorname{LSD} 0.04(P=0.05)$ and $0.06(P=0.01)$ used for comparing mean harvest index of the three resistance groups. 
rAUDPC and FDR were negatively correlated to the number of days to physiological maturity, whereas no correlation was found with the number of days to heading.

\section{DISCUSSION}

Yield losses despite immunity to leaf rust. In our study, yield reductions in the nonprotected compared with the fungicideprotected treatment were negligible for most of the durum wheat genotypes with race-specific resistance. However, significant yield losses were observed in some durum wheat lines that were immune to the $P$. triticina race $\mathrm{BBG} / \mathrm{BN}$.

Sayre et al. (22) found that leaf rust caused losses irrespective of the level of resistance possessed by the cultivars. Smedegaard-Petersen and Tolstrup (30), who studied powdery mildew resistance in barley, argued that the fact that highly resistant plants do not show any visible disease symptoms after inoculation does not mean that the plants are not affected.
The plants respond to inoculation with energy-demanding physiological processes, probably defense reactions, using stored host energy that otherwise would go to growth and seed production. In addition, a reduction in photosynthetic leaf area due to hypersensitive flecking also can cause yield reductions (20). The use of broadspectrum systemic fungicides often results in yield increases. Fungicide treatments with triazoles (to which group tebuconazole belongs) have been shown to have a beneficial effect on the plants by delaying senescence, thereby prolonging the duration of green leaf area and increasing yield $(1,12,30)$.

Tolerance to leaf rust in durum genotypes. Tolerance is the ability of plants to maintain yield (or quality) performance in the presence of disease symptoms or when the plants appear susceptible to the disease $(4,7,14,23)$. Individual components of yield are less likely to describe disease effects on yield than the yield measure- ment itself. Yield loss, rather than yield performance or disease development, should more accurately reflect the tolerance of a cultivar $(4,7)$. At the same time, it is important to take into account yield performance per se because a highyielding line with high leaf rust tolerance will have a superior value for wheat breeders and producers.

The slow-rusting genotypes Knipa, Planeta 1, Trile, Amic, Manutara, and Planeta 2 showed the lowest yield losses across trials. When the susceptible checks had yield losses of about $60 \%$ across trials, the slow-rusting durum wheat lines lost less than 30\%. Except for Amic and Manutara, the other four slow-rusting durum wheat genotypes had the lowest rAUDPC and FDR values compared with the rest of the genotypes with slow-rusting resistance. In contrast, Amic had intermediate rAUDPC and FDR values, whereas Manutara had values that were among the highest for slow-rusting genotypes. This indi-

Table 4. Kernel weight, kernels per square meter, and test weight for 30 durum wheat genotypes across trials in fungicide-protected (Prot) and nonprotected (Nonprot) treatment and percentage losses ${ }^{\mathrm{a}}$

\begin{tabular}{|c|c|c|c|c|c|c|c|c|c|}
\hline \multirow[b]{2}{*}{ Group, genotype $\mathrm{e}^{\mathrm{e}}$} & \multicolumn{3}{|c|}{ Kernel weight $(\mathrm{mg})^{\mathbf{b}}$} & \multicolumn{3}{|c|}{ Kernels/m ${ }^{2 c}$} & \multicolumn{3}{|c|}{ Test weight $(\mathrm{kg} / \mathrm{hl})^{\mathrm{d}}$} \\
\hline & Prot & Nonprot & Loss $(\%)$ & Prot & Nonprot & Loss $(\%)$ & Prot & Nonprot & Loss (\%) \\
\hline \multicolumn{10}{|l|}{ Susceptible } \\
\hline Atil C2000 & 37.3 & 27.8 & $25.4 * *$ & 17,355 & 8,411 & $51.5 * *$ & 78.9 & 70.2 & $11.0 * *$ \\
\hline Altar C84 & 38.6 & 31.2 & $19.2 * *$ & 14,587 & 9,451 & $35.2 * *$ & 82.0 & 75.3 & $8.1^{* *}$ \\
\hline Mean & 38.1 & 28.7 & $24.7 * * \mathrm{f}$ & 16,037 & 8,931 & $44.3 * * \mathrm{~g}$ & 80.4 & 72.2 & $10.1 * * \mathrm{~h}$ \\
\hline \multicolumn{10}{|l|}{ Race-specific } \\
\hline Jupare C2001 & 38.9 & 36.7 & 5.7 & 15,597 & 15,428 & 1.1 & 80.9 & 80.8 & 0.1 \\
\hline Somateria & 42.7 & 42.1 & 1.3 & 11,262 & 11,094 & 1.5 & 79.6 & 80.2 & -0.7 \\
\hline Camayo & 42.5 & 38.1 & $10.4^{*}$ & 13,955 & 12,758 & 8.6 & 81.8 & 80.0 & 2.2 \\
\hline Storlom & 41.3 & 39.9 & 3.5 & 13,738 & 12,846 & 6.5 & 82.9 & 82.2 & 0.8 \\
\hline Hualita & 36.4 & 34.7 & 4.5 & 15,127 & 14,885 & 1.6 & 78.7 & 78.7 & 0.0 \\
\hline Guayacan2 & 49.9 & 47.4 & 4.9 & 12,892 & 11,846 & 8.1 & 80.8 & 80.2 & 0.7 \\
\hline Pohowera & 30.7 & 29.2 & 5.2 & 13,073 & 12,459 & 4.7 & 74.6 & 73.6 & 1.4 \\
\hline Llareta INIA & 39.7 & 38.2 & 3.9 & 14,071 & 12,992 & 7.7 & 80.0 & 79.4 & 0.7 \\
\hline Guayacán INIA & 45.0 & 42.7 & 5.0 & 12,843 & 12,679 & 1.3 & 79.0 & 79.5 & -0.7 \\
\hline Quetru & 44.4 & 37.9 & $14.6 * *$ & 13,495 & 11,841 & 12.3 & 81.8 & 78.9 & $3.6^{*}$ \\
\hline Mean & 41.0 & 39.3 & $4.2^{\mathrm{f}}$ & 13,558 & 13,158 & $3.0^{\mathrm{g}}$ & 79.9 & 79.6 & $0.5^{\mathrm{h}}$ \\
\hline \multicolumn{10}{|l|}{ Slow-rusting } \\
\hline Snitan & 40.7 & 34.0 & $16.5 * *$ & 15,551 & 12,060 & $22.5^{*}$ & 81.7 & 77.9 & $4.7 * *$ \\
\hline Guanay & 36.4 & 30.8 & $15.4 * *$ & 15,070 & 11,852 & $21.4^{*}$ & 79.6 & 75.7 & $4.8^{* *}$ \\
\hline Huasito & 40.6 & 33.7 & $16.9 * *$ & 14,256 & 11,065 & $22.4^{*}$ & 80.2 & 76.6 & $4.5^{* *}$ \\
\hline Playero & 36.0 & 31.0 & $14.1 *$ & 13,652 & 10,022 & $26.6 * *$ & 78.4 & 74.3 & $5.2 * *$ \\
\hline Molinero & 43.5 & 38.1 & $12.4 * *$ & 13,812 & 10,395 & $24.7 *$ & 81.1 & 77.6 & $4.3 * *$ \\
\hline Planeta 1 & 33.7 & 29.5 & $12.5^{*}$ & 15,593 & 12,982 & 16.7 & 78.3 & 75.3 & $3.9 *$ \\
\hline Planeta 2 & 34.6 & 29.3 & $15.1^{*}$ & 15,627 & 12,990 & 16.9 & 78.4 & 74.2 & $5.3 * *$ \\
\hline Piquero & 39.3 & 33.4 & $14.9 * *$ & 14,310 & 10,182 & $28.8 * *$ & 80.9 & 76.7 & $5.2 * *$ \\
\hline Bergand & 37.5 & 31.9 & $15.0 * *$ & 14,873 & 11,706 & $21.3 *$ & 82.6 & 80.2 & 2.9 \\
\hline Lile & 39.1 & 34.1 & $12.8 *$ & 14,492 & 11,261 & $22.3 *$ & 80.2 & 76.2 & $5.0 * *$ \\
\hline Amic & 34.2 & 29.6 & $13.4 *$ & 16,109 & 13,422 & 16.7 & 82.9 & 79.9 & $3.6^{*}$ \\
\hline Manutara & 45.0 & 39.0 & $13.2 * *$ & 14,474 & 12,043 & 16.8 & 83.9 & 82.2 & 1.9 \\
\hline Knipa & 35.3 & 32.4 & 8.3 & 14,768 & 12,307 & 16.7 & 81.7 & 79.9 & 2.2 \\
\hline Tadiz & 38.1 & 31.1 & $18.3 * *$ & 13,556 & 8,750 & $35.5 * *$ & 80.5 & 74.0 & $8.0 * *$ \\
\hline Trile & 35.8 & 31.7 & $11.5^{*}$ & 14,782 & 12,179 & 17.6 & 81.7 & 79.7 & 2.4 \\
\hline Tagua & 43.2 & 37.1 & $13.9 * *$ & 13,755 & 11,145 & 19.0 & 81.8 & 78.0 & $4.6^{* *}$ \\
\hline Cuca & 41.5 & 34.8 & $16.0 * *$ & 15,500 & 10,978 & $29.2 * *$ & 79.9 & 75.8 & $5.1 * *$ \\
\hline Yavaros C79 & 42.4 & 36.5 & $13.7 * *$ & 13,456 & 10,285 & $23.6^{*}$ & 81.5 & 77.6 & $4.8 * *$ \\
\hline Mean & 38.8 & 33.0 & $14.9 * * \mathrm{f}$ & 14,665 & 11,338 & $22.7 * \mathrm{~g}$ & 80.9 & 77.3 & $4.5 * * h$ \\
\hline
\end{tabular}

${ }^{\text {a }}$ Asterisks $*$ and $* *=$ significant at $P=0.05$ and 0.01 , respectively.

${ }^{\mathrm{b}}$ Least significant difference $(\mathrm{LSD})=4.1(P=0.05)$ and $5.3(P=0.01)$.

${ }^{\mathrm{c}} \mathrm{LSD}=2,695(P=0.05)$ and $3,542(P=0.01)$.

${ }^{\mathrm{d}} \mathrm{LSD}=2.4(P=0.05)$ and $3.2(P=0.01)$.

e Resistance group and genotype.

${ }^{\mathrm{f}}$ LSD $2.7(P=0.05)$ and $4.3(P=0.01)$ used for comparing mean kernel weight of the three groups.

${ }^{\mathrm{g}}$ LSD $2841(P=0.05)$ and $4542(P=0.01)$ used for comparing mean kernels $/ \mathrm{m}^{2}$ of the three groups.

${ }^{\mathrm{h}} \operatorname{LSD} 1.9(P=0.05)$ and $3.0(P=0.01)$ used for comparing mean test weight of the three groups. 
cates that Amic and especially Manutara could carry some level of tolerance to leaf rust. Manutara, Snitan, and Cuca had an average grain yield potential similar to the highest yielding commercial Atil C2000 in fungicide-protected trials. These three slow-rusting durum wheat lines are good parents for crossing with other slowrusting lines that have better resistance, but lower grain yield potential, in order to achieve high yield potential with high levels of resistance.

Yield traits affected by leaf rust. In our study, yield losses due to leaf rust were mostly attributed to a reduction in number of kernels per square meter. The period 20 to 30 days before and after anthesis is critical in determining the number of kernels in spikes and, eventually, determining the number of kernels per square meter, whereas the grainfilling period is critical in determining the kernel weight $(6,32)$. Overall, for environmental effects on yield potential in the absence of biotic stresses, the period before and just after anthesis is more critical than the grain-filling period (6). In our study, leaf rust appeared at earlier plant development stages, especially in the latesown trial; thus, both kernel number and size were seriously affected.

In 2001, a preliminary evaluation of Yavaros C79, Altar C84, Jupare C2001, Camayo, Somateria, Guayacan 2, and Snitan for grain yield, test weight, and kernel weight was undertaken at the same location using the same race, $\mathrm{BBG} / \mathrm{BN}$, by Singh et al. (27). The trial differed in that the sowing date was 8 December 2004 and the inoculation was carried out 1 month later than in this study (20 February). As would be expected, the grain yield losses of these cultivars between the protected and nonprotected plots generally were much lower and the yield losses were attributed mainly to changes in kernel weight.

In a similar study by Sayre et al. (22), grain yield losses due to leaf rust in bread wheat were associated with reductions in kernel weight, kernels per square meter, spikes per square meter, and grain-filling rate. Singh and Huerta-Espino (26) investigated the effect of the slow-rusting gene Lr34 in bread wheat and found that yield losses due to leaf rust was associated with biomass, kernel weight, kernels per spike, harvest index, and test weight. This relationship between reduction in kernel weight and yield losses caused by rust has been found by many authors $(5,13,19$, 26,29,31). In addition, the test weight, which is a function of size and weight/ density of individual kernels, has been shown to be affected by rust in several studies $(5,9,19,20,26)$.

Breeding strategies. Selection for high yielding bread wheats with 10 to $20 \%$ leaf rust severity has been practiced at CIMMYT for more than 30 years (16). This has not been the case with durum wheat because more than $80 \%$ of CIMMYT germ plasm was protected by the same resistance gene (27), which remained effective for 16 years during the time when the leaf rust race $\mathrm{BBB} / \mathrm{BN}$ predominated in durum wheat fields (25). When the resistance conferred by this gene was no longer effective, the remaining resistance may have been lower because there had been no selection for slow-rusting (horizontal) resistance (33). Our results indicate that losses due to leaf rust in slow-rusting durum wheat lines are higher than in slowrusting bread wheat genotypes with similar disease levels when evaluated at the same location and with susceptible checks showing similar losses $(22,26)$. However, comparison between bread wheat and durum wheat should be made with caution because leaf rust races attacking these two species are different $(11,25,27)$. Durum wheat also is more sensitive than bread wheat to environmental conditions during spike development and grain determination, which also could explain the difference in yield losses (17).

Disease pressures as realized in our studies are not common in commercial fields, even in northwestern Mexico, except under conditions with very late sowing. Therefore, the level of slow-rusting resistance in some of the best durum wheat genotypes could be sufficient to protect the crop in a large-scale production area where inoculum must be produced on the slowrusting genotypes for the disease to progress.

Pyramiding multiple slow-rusting genes through intercrossing genotypes with slow-rusting resistance should be an attractive breeding strategy, as has been demonstrated with bread wheat (28), to develop high-yielding durum wheat lines with trace levels of leaf rust severity and negligible losses even under high disease pressure. In bread wheat, the use of this type of resistance has been shown to be of a more durable type than race-specific resistance. The genetic basis and genetic diversity of such resistance requires further study and understanding. To meet these objectives, populations for genetic and molecular mapping studies are currently being developed, as well as breeding populations derived from complex crosses involving three to four slowrusting parents that are being advanced to higher generations.

Table 5. Genotypic correlations among grain yield, yield loss, various yield traits, area under the disease progress curve (AUDPC), and final disease rating (FDR) of 30 durum wheat genotypes in fungicide-protected (Prot) and nonprotected (Nonprot) treatments ${ }^{\mathrm{a}}$

\begin{tabular}{|c|c|c|c|c|c|c|c|c|c|c|c|c|c|}
\hline Variable & Treatment & Yield & Yield loss & Biomass & $\begin{array}{c}\text { Harvest } \\
\text { index }\end{array}$ & $\begin{array}{l}\text { Kernel } \\
\text { weight }\end{array}$ & $\begin{array}{c}\text { Kernels/ } \\
\mathbf{m}^{\mathbf{2}}\end{array}$ & $\begin{array}{c}\text { Kernels/ } \\
\text { spike }\end{array}$ & $\begin{array}{c}\text { Spikes/ } \\
\mathbf{m}^{2}\end{array}$ & $\begin{array}{c}\text { Test } \\
\text { weight }\end{array}$ & Heading & Maturity & AUDPC \\
\hline \multirow[t]{2}{*}{ Yield loss } & Nonprot & $-0.87 * *$ & $\ldots$ & $\ldots$ & $\ldots$ & $\ldots$ & $\ldots$ & $\ldots$ & $\ldots$ & $\ldots$ & $\ldots$ & $\ldots$ & $\ldots$ \\
\hline & Prot & 0.31 & $\ldots$ & $\ldots$ & $\ldots$ & $\ldots$ & $\ldots$ & $\ldots$ & $\ldots$ & $\ldots$ & $\ldots$ & $\ldots$ & $\ldots$ \\
\hline \multirow[t]{2}{*}{ Biomass } & Nonprot & $0.93 * *$ & $-0.83 * *$ & $\ldots$ & $\ldots$ & $\ldots$ & $\ldots$ & $\ldots$ & $\ldots$ & $\ldots$ & $\ldots$ & $\ldots$ & $\ldots$ \\
\hline & Prot & $0.81 * *$ & $0.54 * *$ & $\ldots$ & $\ldots$ & $\ldots$ & $\ldots$ & $\ldots$ & $\ldots$ & $\ldots$ & $\cdots$ & $\cdots$ & $\cdots$ \\
\hline \multirow[t]{2}{*}{ Harvest index } & Nonprot & $0.98 * *$ & $-0.82 * *$ & $0.74 * *$ & $\ldots$ & $\ldots$ & $\ldots$ & $\ldots$ & $\ldots$ & $\ldots$ & $\ldots$ & $\ldots$ & $\cdots$ \\
\hline & Prot & $0.84 * *$ & -0.01 & 0.32 & $\ldots$ & $\ldots$ & $\ldots$ & $\ldots$ & $\ldots$ & $\ldots$ & $\ldots$ & $\ldots$ & $\ldots$ \\
\hline \multirow[t]{2}{*}{ Kernel weight } & Nonprot & $0.77 * *$ & $-0.65^{* *}$ & $0.72 * *$ & $0.75^{* *}$ & $\ldots$ & $\ldots$ & $\ldots$ & $\ldots$ & $\ldots$ & $\ldots$ & $\ldots$ & $\ldots$ \\
\hline & Prot & $0.60 * *$ & -0.14 & $0.47 * *$ & $0.51 * *$ & $\ldots$ & $\ldots$ & $\ldots$ & $\ldots$ & $\ldots$ & $\ldots$ & $\ldots$ & $\ldots$ \\
\hline \multirow[t]{2}{*}{ Kernels $/ \mathrm{m}^{2}$} & Nonprot & $0.82 * *$ & $-0.76^{* *}$ & $0.77 * *$ & $0.74 * *$ & 0.26 & $\ldots$ & $\ldots$ & $\ldots$ & $\ldots$ & $\ldots$ & $\ldots$ & $\ldots$ \\
\hline & Prot & $0.40 *$ & $0.44 *$ & 0.33 & 0.32 & $-0.49 * *$ & $\ldots$ & $\ldots$ & $\ldots$ & $\ldots$ & $\ldots$ & $\ldots$ & $\ldots$ \\
\hline \multirow[t]{2}{*}{ Kernels/spike } & Nonprot & $0.81 * *$ & $-0.58 * *$ & $0.59 * *$ & $0.76 * *$ & $0.41^{*}$ & $0.76 * *$ & $\ldots$ & $\ldots$ & $\ldots$ & $\ldots$ & $\ldots$ & $\ldots$ \\
\hline & Prot & 0.33 & 0.24 & 0.19 & 0.31 & $-0.38 *$ & $0.76 * *$ & $\ldots$ & $\ldots$ & $\ldots$ & $\ldots$ & $\ldots$ & $\ldots$ \\
\hline \multirow[t]{2}{*}{ Spikes $/ \mathrm{m}^{2}$} & Nonprot & $0.58 * *$ & $-0.66^{* *}$ & $0.69 * *$ & $0.41 *$ & 0.13 & $0.81 * *$ & 0.11 & $\ldots$ & $\ldots$ & $\ldots$ & $\cdots$ & $\cdots$ \\
\hline & Prot & 0.12 & 0.26 & 0.17 & -0.01 & -0.27 & $0.46 * *$ & -0.29 & $\ldots$ & $\ldots$ & $\ldots$ & $\ldots$ & $\ldots$ \\
\hline \multirow[t]{2}{*}{ Test weight } & Nonprot & $0.79 * *$ & $-0.66 * *$ & $0.72 * *$ & $0.79 * *$ & $0.67 * *$ & $0.59 * *$ & $0.71 * *$ & 0.33 & $\ldots$ & $\ldots$ & $\ldots$ & $\ldots$ \\
\hline & Prot & $0.52 * *$ & 0.17 & 0.28 & $0.55 * *$ & $0.46 * *$ & 0.04 & 0.26 & $-0.37 *$ & $\ldots$ & $\ldots$ & $\ldots$ & $\ldots$ \\
\hline \multirow[t]{2}{*}{ Heading } & Nonprot & -0.36 & -0.09 & -0.22 & $-0.48 * *$ & $-0.41 *$ & -0.14 & -0.35 & 0.02 & -0.32 & $\cdots$ & $\cdots$ & $\cdots$ \\
\hline & Prot & $-0.82 * *$ & -0.08 & $-0.39 *$ & $-0.94 * *$ & $-0.64 * *$ & -0.16 & $-0.37 *$ & 0.15 & $-0.53 * *$ & $\ldots$ & $\ldots$ & $\ldots$ \\
\hline \multirow[t]{2}{*}{ Maturity } & Nonprot & 0.03 & $-0.46^{*}$ & 0.10 & -0.05 & -0.07 & 0.15 & -0.03 & 0.21 & 0.07 & $1.00 * *$ & $\ldots$ & $\ldots$ \\
\hline & Prot & $-0.68 * *$ & -0.14 & -0.17 & $-0.83 * *$ & $-0.49 * *$ & -0.16 & $-0.45^{*}$ & 0.35 & $-0.40 *$ & 1.00 & $\ldots$ & $\ldots$ \\
\hline AUDPC & Nonprot & $-0.66^{* *}$ & $0.86 * *$ & $-0.73^{* *}$ & $-0.48 * *$ & $-0.45^{*}$ & $-0.64 * *$ & $-0.41 *$ & $-0.57 * *$ & $-0.52 * *$ & -0.29 & $-0.52 * *$ & $\ldots$ \\
\hline FDR & Nonprot & $-0.62 * *$ & $0.86 * *$ & $-0.72 * *$ & $-0.48 * *$ & $-0.39 *$ & $-0.67 * *$ & $-0.51 * *$ & $-0.57 * *$ & $-0.47 * *$ & -0.32 & $-0.54 * *$ & $0.99 * *$ \\
\hline
\end{tabular}

${ }^{a}$ Asterisks * and $* *=$ significant at $P=0.05$ and 0.01 , respectively. 


\section{ACKNOWLEDGMENTS}

We thank the Swedish Agency for Research Cooperation with Developing Countries (SIDASAREC) and CIMMYT for financial support, and D. Poland for providing technical editing.

\section{LITERATURE CITED}

1. Bertelsen, J. R., de Neergaard, E., and Smedegaard-Petersen, V. 2001. Fungicidal effects of azoxystrobin and epoxiconazole on phyllosphere fungi, senescence and yield of winter wheat. Plant Pathol. 50:190-205.

2. Burgeno, J., Cadena, A., Crossa, J., Banzinger, M., Gilmour, A. R., and Cullis, B. R. 2000. User's Guide for Spatial Analysis of Field Variety Trials using ASREML. CIMMYT, Mexico, D.F.

3. Caldwell, R. M. 1968. Breeding for general and/or specific plant disease resistance. In: International Wheat Genetic Symposium, 3rd. K. W. Shepherd, ed. Academy of Science, Canberra, Australia.

4. Caldwell, R. M., Schafer, J. F., Compton, L. E., and Patterson, F. L. 1958. Tolerance to cereal leaf rusts. Science 128:714-15.

5. Chester, K. W. 1946. The Cereal Rusts. Chronica Botanica Co., Waltham, MA.

6. Fischer, R. A. 2001. Selection Traits for Improving Yield Potential. CIMMYT, Mexico, D.F.

7. Gaunt, R. E. 1981. Disease tolerance-an indicator of thresholds? Phytopathology 71:915916

8. Gilmour, R. A., Gogel, B. J., Cullis, B. R., Welham, S. J., and Thompson, R. 2002. ASReml User Guide Release 1.0. VSN International Ltd., Hemel Hempsted, HP1 1ES, UK.

9. Griffey, C. A., and Das, M. K. 1994. Yield losses in winter barley resulting from a new race of Puccinia hordei in North America. Plant Dis. 78:256-260.

10. Herrera-Foessel, S. A., Singh, R. P., HuertaEspino, J., Yuen, J., and Djurle, A. 2005. New genes for leaf rust resistance in CIMMYT durum wheats. Plant Dis. 89:809-814

11. Huerta-Espino, J., and Roelfs, A. P. 1989.
Physiological specialization of leaf rust on durum wheat. (Abstr.) Phytopathology 79:1218.

12. James, W. C. 1974. Assessment of plant diseases and losses. Annu. Rev. Phytopathol. 12:24-48.

13. Keed, B. R., and White, N. H. 1972. Quantitative effects of leaf and stem rusts on yield and quality of wheat. Aust. J. Exp. Agric. Anim. Husb. 11:550-555.

14. Parker, S. R., Welham, S. Paveley, N. D., Foulkes, J., and Scott, R. K. 2004. Tolerance to Septoria leaf blotch in winter wheat. Plant Pathol. 53:1-10.

15. Peterson, R. F., Campbell, A. B., and Hannah, A. E. 1948. A diagrammatic scale for estimating rust intensity on leaves and stems of cereals. Can. J. Res. 26:496-500.

16. Rajaram, S., Singh, R. P., and Torres, E. 1988. Current CIMMYT approaches in breeding wheat for rust resistance. In: Breeding Strategies for Resistance to the Rusts of Wheat. N. Simmonds and S. Rajaram, eds. CIMMYT, Mexico, D.F.

17. Reynolds, M. P., Trethowan, R., Crossa, J., Vargas, M., and Sayre, K. D. 2004. Erratum to "Physiological factors associated with genotype by environment interaction in wheat." Field Crop Res. 85:253-274.

18. Roelfs, A. P., Singh, R. P., and Saari, E. E. 1992. Rust diseases of wheat: Concepts and methods of disease management. CIMMYT, Mexico, D.F

19. Salazar Huerta, F. J., Figueroa Lopez, P., and Singh, R. P. 1993. Estimation of potential losses caused by leaf rust (Puccinia recondita Rob. ex Desm.) on wheat in southern Sonora. Rev. Mex. Fitopatol. 11:41-46.

20. Samborski, D. J., and Peturson, B. 1960. Effect of leaf rust on the yield of resistant wheats. Can. J. Plant Sci. 40:620-22.

21. SAS Institute, Inc. 1999. SAS/STAT User's Guide, Version 8. SAS institute Inc., Cary, NC.

22. Sayre, K. D., Singh, R. P., Huerta-Espino, J., and Rajaram, S. 1998. Genetic progress in reducing losses to leaf rust in CIMMYT-derived Mexican spring wheat cultivars. Crop Sci.
38:654-659.

23. Schafer, J. F. 1971. Tolerance to plant disease. Annu. Rev. Phytopathol. 9:235-250.

24. Singh, R. K., and Chaudhary, B. D. 1979. Biometrical Methods in Quantitative Genetic Analysis. Kalyani Publishers, New Delhi, India.

25. Singh, R. P. 1991. Pathogenicity variations of Puccinia recondita $\mathrm{f}$. $\mathrm{sp}$. tritici and $P$. graminis f. sp. tritici in wheat-growing areas of Mexico during 1988 and 1989. Plant Dis. 75:790-794.

26. Singh, R. P., and Huerta-Espino, J. 1994. Effect of leaf rust gene Lr34 on grain yield and agronomic traits of spring wheat. Crop Sci. 37:390-395.

27. Singh, R. P., Huerta-Espino, J., Pfeiffer, W., and Figueroa-Lopez, P. 2004. Occurrence and impact of a new leaf rust race on durum wheat in Northwestern Mexico from 2001 to 2003. Plant Dis. 88:703-708.

28. Singh, R. P., Huerta-Espino, J., and Rajaram, S. 2000. Achieving near-immunity to leaf and stripe rusts in wheat by combining slow rusting resistance genes. Acta Phytopathol. Entomol. Hung. 35:133-139.

29. Singh, R. P., Payne, T. S., Figueroa, P., and Valenzuela, S. 1991. Comparison of the effect of leaf rust on the grain yield of resistant, partially resistant, and susceptible spring wheat cultivars. Am. J. Alt. Agric. 6:115-121.

30. Smedegaard-Petersen, V., and Tolstrup, K. 1985. The limiting effect of disease resistance on yield. Annu. Rev. Phytopathol. 23:475-490.

31. Subba-Rao, K. V., Snow, J. P., and Berggren, G. T. 1989. Effect of growth stage and initial inoculum level on leaf rust development and yield loss caused by Puccinia recondita f. sp. tritici. Journal of Phytopathology 127:200-210.

32. Teng, P. S., and Gaunt, R. E. 1980-81. Modelling systems of disease and yield loss in cereals. Agric. Syst. 6:131-154.

33. Vanderplank, J. E. 1968. Disease Resistance in Plants. Academic Press, New York.

34. Zadoks, J. C., Chang, T. T., and Konzak, C. F. 1974. A decimal code for the growth stages of cereals. Weed Res. 14:415-421. 